\title{
Value of counting colonic mucosal Ig-containing cells in the differential diagnosis of chronic inflammatory bowel disease
}

\author{
C A Seldenrijk, S G M Meuwissen, N W Schipper, B C Morson, J Lindeman, \\ C J L M Meijer
}

\begin{abstract}
Aims: To investigate whether counting cells containing immunoglobulin (Ig) subclass in colonic biopsy specimens of patients with chronic inflammatory bowel disease, in addition to conventional histological evaluation, can improve the differentiation of patients with Crohn's disease from those with ulcerative colitis.
\end{abstract}

Methods: The colonic and rectal biopsy specimens of 40 patients with chronic inflammatory bowel disease, comprising 20 patients with Crohn's disease and 20 with ulcerative colitis, were used and sections were stained specifically for $\operatorname{Ig} A$, IgM, and IgG heavy chains using an indirect immune peroxidase method. The immunoglobulin subclass containing cells were counted using an ocular grid counting method in a light microscope. A linear stepwise discriminant analysis was performed on Ig subclass containing cell counts in combination with 16 reproducible histological features. The results of this discriminant analysis were compared with the results of the discriminant analyses in which only the histological features were used.

Results: Applying stepwise discriminant analysis, two histological features (an excess of histiocytes in the lamina propria and the villous or irregular aspect of the mucosal surface) in combination with IgMmax were selected as the most discriminatory parameters that distinguish Crohn's disease from ulcerative colitis. IgMmax was defined as the maximum value of the mean percentage of IgM containing cells over all the biopsy locations. The use of this combination resulted in a better classification in $20 \%$ of the patients with Crohn's disease and in $9 \%$ of the patients with ulcerative colitis compared with the use of histological features alone.

Conclusions: Morphometric enumeration of Ig subclass containing cells in colonic mucosal biopsy specimens has diagnostic value as a means of differentiating individual patients with Crohn's disease from those with ulcerative colitis.
Differentiation of chronic inflammatory bowel disease (CIBD) in Crohn's disease and ulcerative colitis is important from the clinical and surgical point of view. ${ }^{12}$ Although the biopsy features of acute self limiting colitis and CIBD have been well described and criteria for distinguishing between them have been validated statistically, ${ }^{3}$ studies on the Crohn's disease features that distinguish from ulcerative colitis are scarce. ${ }^{4-7}$

In a previous study ${ }^{8}$ we determined which histological features in colonic biopsy specimens are reproducible. Moreover, using multivariate discriminant analysis, we selected the combination of excess histiocytes in the lamina propria, the aspect of the mucosal surface, and the presence of granulomas as the most useful features for making a reliable distinction between Crohn's disease and ulcerative colitis. With these features $70 \%$ of those with Crohn's disease and $75 \%$ of those patients with ulcerative colitis were correctly classified with a high a posteriori probability $(>0.85)$. The false positive rate was $10 \%$ for Crohn's disease and $4 \%$ for ulcerative colitis. ${ }^{8}$

Several studies have shown differences between the number of immunoglobulin (Ig) containing cells in the lamina propria of colonic and rectal biopsy specimens of patients with Crohn's disease and those with ulcerative colitis. ${ }^{9-15}$ IgM containing cells tend to be increased in colonic biopsy specimens from patients with Crohn's disease compared with those with ulcerative colitis, ${ }^{9-11}$ and this finding has subsequently been confirmed in surgical colonic resection specimens. ${ }^{1516}$ These studies, however, are concerned only with differences in Ig subclass bearing cells in groups of patients with ulcerative colitis or Crohn's disease. The predictive value of counts of Ig containing cells in undiagnosed patients to distinguish Crohn's disease from ulcerative colitis has not been elucidated in these studies. To our knowledge, only Jenkins et $a l^{56}$ investigated whether Ig cell counting in addition to histological features was useful to differentiate between Crohn's disease and ulcerative colitis in individual patients, but their results were controversial. The aim of the present study was to determine whether counting Ig containing cells in colonic mucosal biopsy specimens of clinically well defined patients in addition to conventional 
histological evaluation ${ }^{8}$ could improve the differentiation of individual patients with Crohn's disease from those with ulcerative colitis.

\section{Methods}

The colonic and rectal biopsy specimens of 40 patients with CIBD, comprising 20 with Crohn's disease (seven men, 13 women; mean age 31.7 years, range $21-62$ years) and 20 with ulcerative colitis ( 13 men, seven women; mean age 37 years, range 15-70 years) were used in this immunohistochemical study. All these clinically defined patients had a colonoscopy or sigmoidoscopy and multiple biopsy specimens were taken, usually from the descending colon, sigmoid, and rectum, and if possible from transverse and ascending colon (table 1). For further clinical information the reader is referred to our previous study. ${ }^{8}$

At least three specimens were taken from each site; therefore, usually nine biopsy specimens per patient were studied, and from some, nine to 15 biopsy specimens. Biopsy specimens were taken from inflamed mucosa (when present), and not from ulcer margins or ulcer debris.

\section{BIOPSY PROCESSING}

As well as routinely (haematoxylin and eosin) stained sections, three consecutive sections were cut at $4 \mu \mathrm{m}$ and stained specifically for IgA, IgM, and IgG heavy chains using an indirect immunoperoxidase method. ${ }^{17}$ In summary, immunoglobulin containing cells were shown using an indirect immunoperoxidase technique with rabbit antisera against human $\alpha$ ( 1 in 400), $\mu$ ( 1 in 400), and $\gamma(1$ in 400) heavy chains (Dakopatts) as first layer and peroxidase labelled mouse anti-rabbit immunoglobulin as second layer. Visualisation was done using $3 \cdot 3$ diaminobenzidine as substrate.

Appropriate controls were done according to the method of Sternberger. ${ }^{18}$ As a negative control, one section of each biopsy specimen was stained with a non-immune rabbit immunoglobulin fraction (Dakopatts) at the same dilution as the specific antiserum.

\section{COUNTS OF Ig CONTAINING CELLS}

This was done according to a new technique with high reproducibility that we recently developed. ${ }^{19}$ In brief Ig containing cells were counted with a light microscope equipped with an ocular counting grid containing 100 squares. The optical parameters were adjusted in such a way (magnification factor 200) that one square of the counting grid corresponded to $0.0025 \mathrm{~mm}^{2}$ (the area of one square). The area of the lamina propria was calculated by multiplying the numbers of squares covering the lamina propria by $0.0025 \mathrm{~mm}^{2}$. A mucosal field was selected in sections of each of the three biopsy specimens from each site with intact full thickness mucosa; this field was delineated by the muscularis mucosae, the surface epithelium, and the lateral boundaries of the ocular grid (fig 1). The selection of the mucosal field was made on the subjective estimation that the field contained the largest number of Ig subclass cells in that biopsy specimen. The Ig subclass containing cells were counted in at least one field of each of the three biopsy specimens from each site. At each biopsy location the mean percentage of $\operatorname{IgM}, \operatorname{IgA}$, and IgG containing cells was calculated. The cell counts were expressed as percentages of the total number of Ig subclass containing cells per $\mathrm{mm}^{2}$ of lamina propria. To stabilise the variation in the running mean of counts of $\mathrm{Ig}$ subclass containing cells per biopsy location at least $600 \mathrm{Ig}$ containing cells had to be counted, as described in our previous study. ${ }^{19}$ Therefore, if after counting of the three mucosal fields the total number of Ig containing cell counts was less than 600 , consecutive fields in each biopsy specimen were selected and Ig containing cells were counted until a total number of 600 Ig containing cells were counted per biopsy location. The reproducibility of this counting method is sufficient to detect differences in the mean counts of IgA and IgG containing cells of more than $10 \%$, whereas the differences in the mean counts of IgM must exceed $5 \% .^{19}$

According to this protocol several parameters were recorded:

1 At each biopsy location, the mean percentage of $\operatorname{IgM}, \operatorname{IgA}$, and $\operatorname{IgG}$ containing cells in the three biopsy specimens (expressed as percentages of the total number of cells per $\mathrm{mm}^{2}$ of lamina propria) was defined as:

$$
\operatorname{IgX} X_{i}=\frac{\operatorname{Ig} X_{\text {biopsy1 }}+\operatorname{Ig} X_{\text {biopsy2 }}+\operatorname{Ig} X_{\text {biopsy3 }}}{3 \text { (= number of biopsy specimens })}
$$

$\mathrm{X}=$ counts of $\operatorname{Ig} M, \operatorname{IgA}$, or $\operatorname{IgG}$ containing cells.

This calculation may be the result of $\operatorname{IgM}_{\text {rectum }}, \operatorname{Ig} A_{\text {rectum }}, \operatorname{IgG}_{\text {rectum }}, \operatorname{Ig} M_{\text {sigmoid }}$, etc.

2 In each patient the mean percentage $\operatorname{IgX}$ (X = IgM, IgA, or IgG) containing cells from all biopsy locations was defined as: the sum of

$$
\Sigma \operatorname{IgX}_{\mathrm{r}}+\underset{\operatorname{Ig} \mathrm{X}_{\mathrm{ac}}}{+\operatorname{Ig} \mathrm{X}_{\mathrm{dc}}}+\operatorname{Ig\mathrm {X}_{\mathrm {tc}}}+
$$

$\operatorname{IgX}=\frac{\text { number of biopsy locations }}{\text { nof }}$

$\mathrm{r}=$ rectum; $\mathrm{s}=$ sigmoid; $\mathrm{dc}, \mathrm{tc}$, and $\mathrm{ac}=$ descending, transverse and ascending colon, respectively.

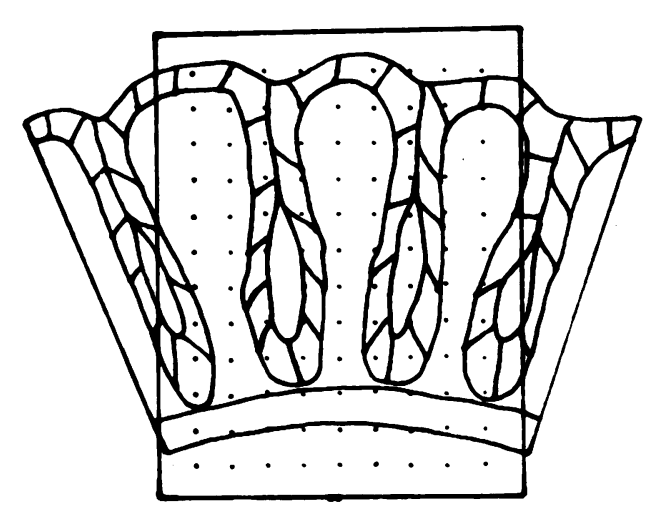

Figure 1 Full thickness mucosal field of a colonic biopsy specimen with an ocular grid of 100 counting points. 
Table 1 Univariate analysis of mean percentage of Ig containing cells per biopsy location

\begin{tabular}{|c|c|c|c|c|c|c|}
\hline \multirow[b]{2}{*}{ Location } & \multirow[b]{2}{*}{ Ig type } & \multicolumn{2}{|c|}{ Crohn's disease } & \multicolumn{2}{|c|}{ Ulcerative colitis } & \multirow{2}{*}{$\begin{array}{l}\text { p Values for } \\
\text { Crohn's disease/ } \\
\text { Ulcerative colitis }\end{array}$} \\
\hline & & $n=\star \star$ & Mean $\% I^{\star}$ & $n=\star \star$ & Mean \% Ig & \\
\hline Rectum & $\begin{array}{l}\text { IgM } \\
\text { IgG } \\
\text { IgA }\end{array}$ & 16 & $\begin{array}{l}13 \\
22 \\
65\end{array}$ & 16 & $\begin{array}{r}9 \\
25 \\
66\end{array}$ & $\begin{array}{l}0 \cdot 1697 \\
0 \cdot 3381 \\
1.0000\end{array}$ \\
\hline Sigmoid colon & $\begin{array}{l}\text { IgM } \\
\text { IgG } \\
\text { IgA }\end{array}$ & 15 & $\begin{array}{l}14 \\
22 \\
64\end{array}$ & 17 & $\begin{array}{r}7 \\
26 \\
66\end{array}$ & $\begin{array}{l}0.0058 \\
0 \cdot 2717 \\
0 \cdot 8110\end{array}$ \\
\hline Descending colon & $\begin{array}{l}\text { IgM } \\
\text { IgG } \\
\text { IgA }\end{array}$ & 14 & $\begin{array}{l}17 \\
26 \\
57\end{array}$ & 14 & $\begin{array}{r}7 \\
21 \\
72\end{array}$ & $\begin{array}{l}0.0001 \\
0 \cdot 1108 \\
0.0113\end{array}$ \\
\hline Transverse colon & $\begin{array}{l}\text { IgM } \\
\text { IgG } \\
\text { IgA }\end{array}$ & 10 & $\begin{array}{l}15 \\
22 \\
63\end{array}$ & 4 & $\begin{array}{l}10 \\
25 \\
65\end{array}$ & $\begin{array}{l}0 \cdot 1178 \\
0 \cdot 2278 \\
0 \cdot 7228\end{array}$ \\
\hline Ascending colon & $\begin{array}{l}\text { IgM } \\
\text { IgG } \\
\text { IgA }\end{array}$ & 5 & $\begin{array}{l}13 \\
26 \\
31\end{array}$ & 3 & $\begin{array}{l}19 \\
26 \\
55\end{array}$ & $\begin{array}{l}0.2410 \\
0 \cdot 5577 \\
0.4344\end{array}$ \\
\hline
\end{tabular}

3 In each patient IgMmax was determined, defined as the maximum value of the mean percentage of $\operatorname{IgM}$ containing cells from all biopsy locations with the corresponding IgG (c-IgG max) and IgA (c-IgA max) of that biopsy location. For example, if the mean $\mathrm{IgM}_{\text {rectum }}$ (as defined under parameter 1 ) is $10 \%$ and the mean $\operatorname{IgM}_{\text {sigmoid }}$ is $20 \%$, the IgMmax of that patient would be $20 \%$. The c-IgG max and c-IgA max are mean percentage $\operatorname{IgG}_{\text {sigmoid }}$ and mean percentage $\operatorname{IgA}_{\text {sigmoid }}$. Twelve per cent of the biopsy specimens $(45)$ 387) could not be counted for several reasons, such as inadequate orientation, ulcer material only, or too much background staining. But there were sufficient biopsy specimens to include each patient in the study except for one patient with ulcerative colitis in whom the biopsy specimens of all three locations showed too much background staining; therefore a total of 19 patients with ulcerative colitis were analysed.

\section{STATISTICAL ANALYSIS}

Univariate analysis

The discriminative power of the mean IgX, mean IgX in a patient, and the IgMmax, with corresponding IgG and IgA to distinguish patients with Crohn's disease from those with ulcerative colitis was investigated through univariate analysis using the non-parametric Mann-Whitney test (Programs P3S of the BMDP statistical software package) ${ }^{20}$ Results with a $p$ value of $<0.05$ were regarded as significant.

\section{Multivariate analysis}

To determine whether counting of Ig containing cells in addition to histological evaluation is useful to differentiate Crohn's disease from ulcerative colitis in patients classified as having chronic inflammatory bowel disease $(n=40)$ two (linear) stepwise discriminant analyses (Program P7M of the BMDP statistical software package) were carried out. ${ }^{20}$ First, a stepwise discriminant analysis was performed on the mean $\operatorname{IgX} X_{i}$, mean $\operatorname{IgX}$ per patient, and IgMmax per patient with the corresponding IgG and IgA to differentiate chronic inflammatory bowel disease in Crohn's disease and ulcerative colitis. Second, a stepwise discriminant analysis was done on these Ig parameters in combination with 16 reproducible histological features described in a previous paper. ${ }^{8}$ The classification results of these two discriminant analyses were compared with the results of the discriminant analysis in which only histological features were used. ${ }^{8}$

\section{Results}

\section{UNIVARIATE ANALYSIS}

The results of the Ig subclass-containing cell counts are shown in table 1 . In patients with Crohn's disease there was a relative increase in the mean percentage of IgM containing cells in all locations compared with patients with ulcerative colitis, except in the ascending colon. In Crohn's disease the mean percentages of IgM containing cells in the sigmoid and descending colon (14\% and $17 \%$, respectively) were significantly different $(p=0.0058$ and $\mathbf{p}=0.0001$, respectively) compared with ulcerative colitis (7\% and $10 \%$, respectively).

In Crohn's disease the range of the mean percentage of IgG and IgA containing cells was $22-26 \%$ and $57-65 \%$; in ulcerative colitis these values varied from $21-26 \%$ and $66-72 \%$, res-

Table 2 Univariate analysis of mean Ig subclass containing cells per patient and IgMmax per patient

\begin{tabular}{llllll}
\hline & & & & & $\begin{array}{c}\text { p Values for } \\
\text { Crohn's diseasel } \\
\text { Ulcerative colitis }\end{array}$ \\
\hline Mean IgM & $n^{\star \star}=$ & Crohn's disease & $n^{\star \star}=$ & Ulcerative colitis & $0 \cdot 005$ \\
Mean IgG & 20 & 14 & 19 & 8 & $0 \cdot 8141$ \\
Mean IgA & & 24 & & 25 & $0 \cdot 2083$ \\
IgMmax & & 62 & 19 & 97 & $0 \cdot 0000$ \\
clgG max & 20 & 18 & & 26 & $0 \cdot 1916$ \\
clgA max & & 25 & 58 & 65 & $0 \cdot 4804$ \\
\hline
\end{tabular}

*Mean percentage Ig containing cells per biopsy location; $\star_{\star}^{*}$ number of patients in which the Ig-containing cells were counted; ${ }^{+}$mean percentage of Ig subclass containing cell per patient; ${ }^{++}$IgMmax is the maximum value of the mean percentage of IgM containing cells found over all biopsy locations in patient; $\operatorname{clgG} \max$ and clgA max are the corresponding values of the mean percentage of IgG and IgA containing cells in that biopsy location. 
pectively. These differences were not significant (table 1).

Both the percentage of IgMmax $(p<0.0001)$ and mean $\operatorname{IgM}(p=0.0005)$ contributed significantly to distinguishing Crohn's disease from ulcerative colitis (table 2).

\section{MULTIVARIATE ANALYSIS}

Ig counting alone

If only Ig subclass containing cell counting was used, IgMmax was selected as the strongest feature to discriminate between Crohn's disease and ulcerative colitis. The addition of other Ig subclass containing cell counts did not result in a better classification. Jackknifed classification of the analysis was performed to evaluate the discriminant function. As in our previous study ${ }^{8}$ values of $0 \cdot 15$ and 0.85 were used as cutoff points for the a posteriori probabilities. A patient was predicted to have ulcerative colitis when the ulcerative colitis a posteriori probability was larger than $0 \cdot 85$, and was diagnosed as having Crohn's disease when the a posteriori probability is smaller than $0 \cdot 15$. Indeterminate CIBD was classified when the a posteriori probability lay between or was equal to $0 \cdot 15$ and $0 \cdot 85$.

Using IgMmax as the discriminant feature eight of $20(35 \%)$ patients with Crohn's disease and seven of $19(37 \%)$ of those with ulcerative colitis were correctly classified (fig 2) and (table $3)$. Twelve out of $20(60 \%)$ patients with Crohn's disease and 12 of $19(63 \%)$ of those with ulcerative colitis were classified as CIBD indeterminate. No false positive diagnoses were made.

Histological features in combination with Ig subclass cell counting

When discriminant analysis was applied to Ig subclass containing cell counting together with conventional reproducible histological features, three discriminants were selected. The presence of an excess of histiocytes emerged as the most discriminant feature, followed by the aspect of the mucosal surface (normal/irregular/villous). Instead of granu-

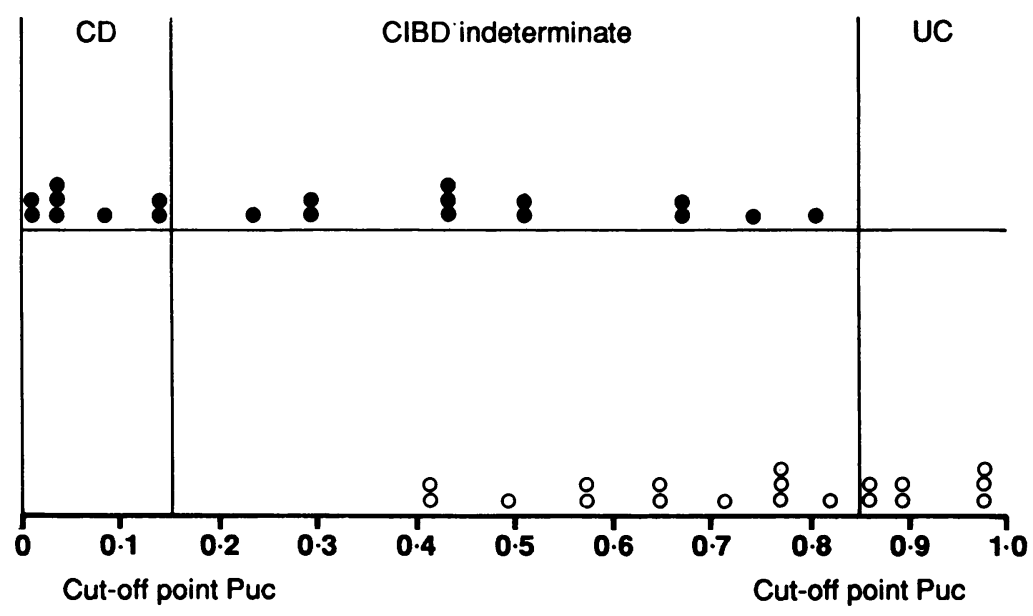

Figure 2 Jackknifed classification results using IgMmax as the discriminant. The CIBD a posteriori probabilities 0.15 and 0.85 were chosen as cutoff points:

$=$ Crohn's disease; $O=$ ulcerative colitis. lomas (selected as the third feature when only histopathological features were included ${ }^{9}$ ), IgMmax was selected as the third most discriminatory feature. Additional histological features or Ig subclass containing cell counts did not offer a higher diagnostic accuracy for the distinction between Crohn's disease and ulcerative colitis.

According to the jackknifed classification, the combination of these three criteria permitted an accurate diagnosis with a high a posteriori probability $(>0.85)$ in 18 of $20(90 \%)$ patients with Crohn's disease and 16 of $19(84 \%)$ with ulcerative colitis (fig 3 and table 3 ). Two out of 19 patients with ulcerative colitis were wrongly diagnosed as having Crohn's disease; no false positive cases of ulcerative colitis were recorded. Two out of $20(10 \%)$ patients with Crohn's disease $(p=0.526$ and $p=0.423)$ and one out of $19(5 \%)$ patients with ulcerative colitis $(p=0.283$ ) were classified as CIBD indeterminate.

When this combination of conventional histological features was applied with additional IgMmax counts (table 3), a higher diagnostic accuracy rate was achieved compared with the use of histological features alone (table 3). The overall classification improved by $20 \%$ (four of 20) for Crohn's disease and $12.5 \%$ (one of 19) for patients with ulcerative colitis. Consequently the number of patients diagnosed as having CIBD indeterminate decreased from $20 \%$ $(8 / 40)$ to $7 \cdot 5 \%(7 / 39)$. Even a small reduction in the number of false positive diagnoses occurred; $5 \%$ (two cases were wrongly classified) instead of $7.5 \%$ (three patients were falsely classified, two with Crohn's disease and one with ulcerative colitis) when conventional histological features with additional IgMmax counts were applied.

\section{Discussion}

In this study we have extended our previous histopathological work ${ }^{8}$ with an immunohistochemical evaluation of colonic mucosal biopsy specimens to investigate whether containing Ig cell counts improved the diagnostic accuracy rate of Crohn's disease and ulcerative colitis compared with the use of histopathological features alone. It is important to emphasise that before the discriminative power of these parameters to differentiate Crohn's disease from ulcerative colitis were evaluated, the reproducibility of the counting method Ig subclass containing cells ${ }^{19}$ as well as the reproducibility of the histopathological features ${ }^{8}$ were extensively tested. As far as we know this is the first study in which reproducible histological features in combination with $\mathrm{Ig}$ subclass containing cell counts were used in a discriminant analysis to determine their diagnostic value to distinguish an individual patient with Crohn's disease from a patient with ulcerative colitis.

Applying multivariate discriminant analysis to Ig counts and the reproducible histopathological features (as described in our previous paper ${ }^{8}$ ), two histological features (an excess of histiocytes and irregular or villous mucosal 
Table 3 Comparison of results of stepwise discriminant analysis with IgMmax counts alone $(A)$, histological features + IgMmax cell counting $(B)$, and histological features alone (C)

\begin{tabular}{|c|c|c|c|c|c|}
\hline$A$ & $\begin{array}{l}\text { Variable entered: } \\
\text { IgMmax }\end{array}$ & $\begin{array}{l}\text { Correct } \\
\text { diagnosis }\end{array}$ & $\begin{array}{l}\text { Incorrect } \\
\text { diagnosis }\end{array}$ & $\begin{array}{l}\text { CIBD } \\
\text { indeterminate }\end{array}$ & Total \\
\hline & $\begin{array}{l}\text { Crohn's disease } \\
\text { Ulcerative colitis } \\
\text { Total }\end{array}$ & $\begin{array}{r}8(35 \%) \\
7(19 \%) \\
15(38 \%)\end{array}$ & $\begin{array}{l}\mathbf{0}(0 \%) \\
\mathbf{0}(0 \%) \\
\mathbf{0}(0 \%)\end{array}$ & $\begin{array}{l}12(60 \%) \\
12(63 \%) \\
24(62 \%)\end{array}$ & $\begin{array}{l}20 \\
19 \\
39\end{array}$ \\
\hline \multirow[t]{2}{*}{$B$} & $\begin{array}{l}\text { Variables entered: } \\
\text { excess of histiocytes in lamina propria/irregular or villous mucosal surface/ } \\
\text { IgMmax }\end{array}$ & & & & \\
\hline & $\begin{array}{l}\text { Crohn's disease } \\
\text { Ulcerative colitis } \\
\text { Total }\end{array}$ & $\begin{array}{l}18(90 \%) \\
16(84 \%) \\
34(87 \%)\end{array}$ & $\begin{array}{l}0(0 \%) \\
2(11 \%) \\
2(5 \%)\end{array}$ & $\begin{array}{l}2(10 \%) \\
1(5 \%) \\
3(8 \%)\end{array}$ & $\begin{array}{l}20 \\
19 \\
39\end{array}$ \\
\hline \multirow[t]{2}{*}{$C$} & $\begin{array}{l}\text { Variables entered: } \\
\text { excess of histiocytes/irregular or villous mucosal surface/granulomas }\end{array}$ & & & & \\
\hline & $\begin{array}{l}\text { Crohn's disease } \\
\text { Ulcerative colitis } \\
\text { Total }\end{array}$ & $\begin{array}{l}14(70 \%) \\
15(75 \%) \\
29(72 \cdot 5 \%)\end{array}$ & $\begin{array}{l}2(10 \%) \\
1(4 \%) \\
3(7 \cdot 5 \%)\end{array}$ & $\begin{array}{l}4(19 \%) \\
4(19 \%) \\
8(20 \%)\end{array}$ & $\begin{array}{l}20 \\
20 \\
40\end{array}$ \\
\hline
\end{tabular}

surface), in combination with IgMmax (defined as the maximum value of the mean percentage of IgM containing cells over all biopsy locations) were selected as criteria with the highest predictive value to differentiate Crohn's disease from ulcerative colitis. The excess of histiocytes and the villous or irregular aspect of the mucosal surface was not necessarily made on the same biopsy specimen which gave the IgMmax. Using this combination, an improvement in the diagnostic accuracy was achieved, in particular for Crohn's disease $(20 \%)$, but also, although to a lesser extent, for ulcerative colitis ( $9 \%$ ) compared with the use of histological features alone. Moreover, the number of incorrect diagnoses and the number of patients classified as CIBD indeterminate decreased to $2.5 \%$ and $12 \%$, respectively. The classifications were made with high a posteriori probabilities $(>0 \cdot 85)$.

Published data on the enumeration of Ig containing cells in colonic mucosa of patients with chronic inflammatory bowel disease show striking discrepancies (table 4). Factors that can account for these discrepancies in Ig containing cell counts include the fixation method, ${ }^{18}$ the staining technique (immunoperoxidase $^{111322}$ compared with immunofluorescence ${ }^{9141823}$ ) and method of quantification. Notwithstanding conflicting results of

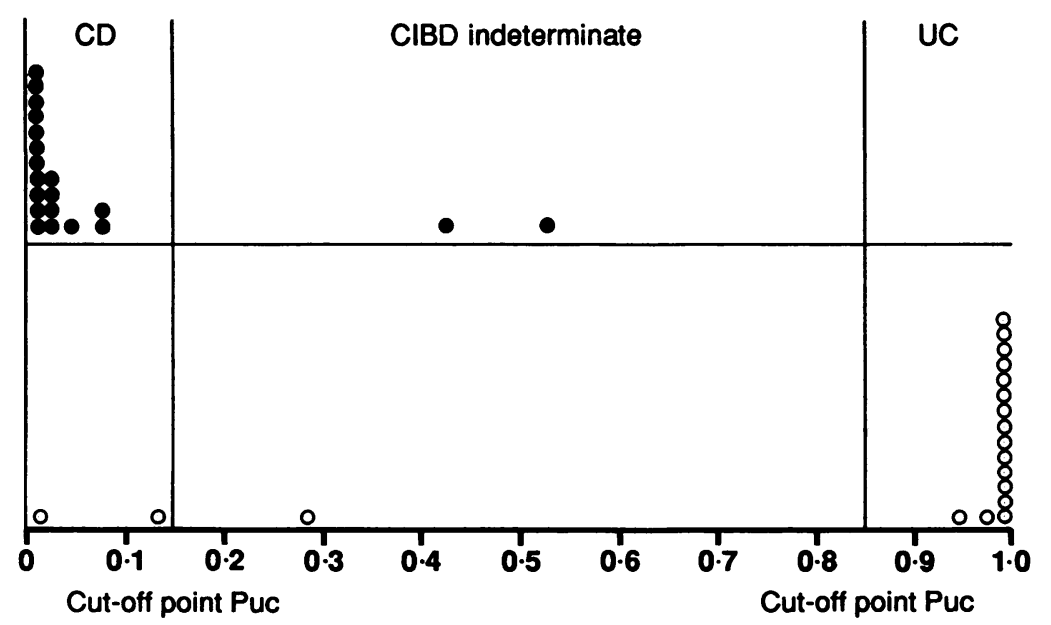

Figure 3 Jackknifed classification results using two histological features (an excess of histiocytes in the lamina propria and the aspect (irregular/villous) of the mucosal surface) in combination with IgMmax. The ulcerative colitis a posteriori probabilities 0.15 and 0.85 were chosen as cutoff points: $\bullet=$ Crohn's disease; $O=$ ulcerative colitis. some studies, ${ }^{591422}$ several other studies reported a tendency towards an increase in mean numbers of IgM containing cells in Crohn's disease $^{610111315222425}$ ). This increase in the mean numbers of IgM containing cells has not only been shown in active disease, ${ }^{15} 22$ but also to a lesser extent in inactive Crohn's disease ${ }^{11}$ and in histologically normal gastric and duodenum biopsy specimens of patients with Crohn's disease. ${ }^{24}$ In most of these studies the observed ranges of Ig containing cells overlapped considerably and this limited their use as a sole discriminatory feature to differentiate Crohn's disease from ulcerative colitis. This agrees with our results as shown in figs 2 and 3 . Using only the maximum value of the mean percentage of IgM containing cells over all the biopsy locations (IgMmax), we did not achieve an improvement of the classification compared with the use of histological features alone (table 3).

Whether additional Ig subclass counting is useful as well as conventional histological features in the differential diagnosis of Crohn's disease and ulcerative colitis has never been elucidated in those studies. Only Jenkins has performed such a morphometric study on rectal biopsy specimens. ${ }^{5} \mathrm{He}$ found that $73 \%$ of the cases could be accurately classified on jackknifed testing by histological measurements alone (standard deviation of intercrypt distance, of crypt lengths, of vertical cell densities and the number of lamina propria cells per unit area). Including counts of IgM containing cells (expressed per mm mucosal length) improved the classification of ulcerative

Table 4 Percentage of mean Ig containing cells over all biopsy locations in large bowel reported by different authors $^{+}$

\begin{tabular}{|c|c|c|c|}
\hline & $\operatorname{Ig} A$ & $I g M$ & $\operatorname{Ig} G$ \\
\hline $\begin{array}{l}\text { Crohn's disease: } \\
\text { Skinner et al } \\
\text { Baklien et al } \text { al }^{21} \\
\text { Rosekrans et al } \text { l }^{16} \\
\text { Present study }\end{array}$ & $\begin{array}{l}87 \cdot 0 \\
62 \cdot 3 \\
54 \\
62\end{array}$ & $\begin{array}{l}4 \cdot 5 \\
10 \cdot 5 \\
33 \\
14\end{array}$ & $\begin{array}{l}8 \cdot 5 \\
27 \cdot 2 \\
13 \\
24\end{array}$ \\
\hline $\begin{array}{l}\text { Ulcerative colitis: } \\
\text { Skinner } \text { et al } \text { al }^{26} \\
\text { Söltoft } \text { et al } \text { al }^{28++} \\
\text { Baklien } \text { et } \text { al }^{21} \\
\text { Rosekrans et al }{ }^{16} \\
\text { Present study }\end{array}$ & $\begin{array}{l}79 \cdot 2 \\
52 \cdot 8 \\
52 \cdot 1 \\
57 \\
67\end{array}$ & $\begin{array}{c}7 \cdot 5 \\
11 \cdot 8 \\
4 \cdot 4 \\
5 \\
8\end{array}$ & $\begin{array}{l}13 \cdot 3 \\
35 \cdot 2 \\
43 \cdot 3 \\
38 \\
25\end{array}$ \\
\hline
\end{tabular}

+The data from other studies were recalculated to make

comparison possible.
${ }^{+}$Rectal biopsy specimens only. 
colitis by almost 15\%; the number of false positive Crohn's disease diagnoses decreased by $15 \% .^{5}$ No change in the number of correct diagnoses of Crohn's disease was recorded. In a recent study, however, Jenkins et al were not able to confirm these results ${ }^{6}$; in their opinion there is a wide range of counts in chronic inflammatory bowel disease and this limits the use of Ig subclass counting in the differentiation between Crohn's disease and ulcerative colitis.

In contrast to these data, in our study IgMmax was selected as the most discriminatory parameter in addition to two histological features. This can be explained by the fact that in our study multiple biopsy specimens from different locations were investigated. It indicates that there are focal differences in the increase in the number of $\operatorname{IgM}$ containing cells. This has already been shown by Keren $e t$ al, ${ }^{23}$ who showed in sites of active inflammation in CIBD that there was a much bigger increase in the mean numbers of $\operatorname{IgM}$ containing cells compared with inactive CIBD. Therefore, when using IgMmax, locations with the most active inflammation are probably selected.

In this study neither patients with acute infectious colitis nor patients with acute infectious colitis superimposed on CIBD were included. However, some investigators ${ }^{27}$ have claimed that counting Ig subclass containing cells in colonic biopsy specimens provides a useful additional criterion in the differential diagnosis of acute infectious colitis and CIBD. ${ }^{26}$ They underline that caution is necessary in patients with acute infectious colitis that runs a protracted course, because the number of IgG containing cells in colonic biopsy specimens from these specimens may be increased as in patients with active CIBD. Therefore it remains to be elucidated whether enumeration of Ig subclass containing cells in colonic biopsy specimens really does have additional value for the individual patient in the differentiation of acute infectious colitis with a protracted course and an infectious colitis superimposed on CIBD.

A relative increase in the number of $\operatorname{IgM}$ containing cells through the whole gastrointestinal tract in patients with Crohn's disease suggests a defect in the switch of IgM to IgA containing plasma cells. Because IgA containing cells are present in the lamina propria and the switch of IgM to IgA is under the control of several types of suppressor cells, it might be that in Crohn's disease a certain subpopulation of suppressor cells is absent or that they have a functional defect. Moreover, until now no satisfactory explanation for the increase of $\operatorname{IgM}$ containing cells in the gastrointestinal tract of patients with Crohn's disease has been offered.

In conclusion our findings support previous suggestions $s^{61011-13}$ that counting Ig subclass containing cells has diagnostic value, differentiating patients with Crohn's disease from those with ulcerative colitis. Using the combination of an excess of histiocytes, the pattern (irregular/villous) of the mucosal surface and IgMmax (defined as the maximum value of the mean percentage of IgM containing cells over all biopsy specimens in a patient) we were able to improve the diagnostic accuracy of Crohn's disease and ulcerative colitis compared with the use of histological features alone. We favour a quantitative approach to determine the percentage of Ig subclass containing cells in the colonic mucosal biopsy specimens of those patients with CIBD in whom, on histological criteria alone, a differentiation between Crohn's disease and ulcerative colitis is difficult.

We thank MrE Boots, MrE Noteboom, Miss T Tadema and Mr W Vos for their excellent technical assistance.

1 Pathology of the colon, small intestine, and anus. In: Norris HT, ed. Contemporary issues in surgical pathology. Vol 2 . New York: Churchill Livingstone, 1983:1-21.

2 Morson BC, Dawson IMP. Gastrointestinal pathology. Oxford: Blackwell Scientific Publication, 1979:523-61.

3 Surawicz CM, Belic L. Rectal biopsy helps to distinguish acute self-limited colitis from idiopathic inflammatory bowel disease. Gastroenterology 1984;86:104-13.

4 Goldman H. Acute versus chronic colitis: how and when to distinguish by biopsy. Gastroenterology 1984;86:199-201.

5 Jenkins D, Goodall A, Drew K, Scott BB. What is colitis? Statistical approach to distinguish clinically important
change in rectal biopsy specimens. J Clin Pathol 1988; change in

6 Jenkins D. Computing and histopathology of intestinal inflammation. In: FR Vicery, ed. Computers in gastroenterology. London: Springer Verlag, 1988:193-204.

7 Thompson EM, Price AB, Altman DG, Sowter C, Slavin G. Quantitation in inflammatory bowel disease using computerized interactive image analysis. J Clin Pathol 1985; 38:631-8.

8 Seldenrijk CA, Morson BC, Meuwissen SGM, Schipper NW, Lindeman J, Meijer CJLM. Histopathological evaluation of colonic mucosal biopsy specimens in chronic inflammatory bowel disease. Gut 1991;32:1514-20.

9 Scott BB, Goodall A, Stephenson P, Jenkins D. Rectal mucosal plasmacells in inflammatory bowel disease. Gut mucosal plasmacell

10 Green FHY, Fox H. The distribution of mucosal antibodies in the bowel of patients with Crohn's disease. Gut 1975;16:125-31.

11 Rosekrans PCM, Meijer CJLM, van der Wal AM, Cornelissen CJ, Lindeman J. Immunoglobulin containing cells in inflammatory bowel disease of the colon: a morphometric and immunohistochemical study. Gut 1980;21:941-7.

12 Meuwissen SGM, Feltkamp-Vroom TM, Brutel de la Rivière, von den Borne AEGK, Tytgat GN. Analysis of the lymphoplasmacytic infiltrates in Crohn's disease with special reference to identification of lymphocytic subspecial reference to identificatio

13 van Spreeuwel JP, Meijer CJLM, Rosekrans PCM, Lindeman J. Immunoglobulin-containing cells in the gastrointestinal pathology: diagnostic implications. In: gastrointestinal pathology: diagnostic implications. In: annual. Norwalk, Connecticut: Appleton-CenturyCrofts, 1986:295-311

4 Söltoft J. Immunoglobulin-containing cells in normal jejunal mucosa and in ulcerative colitis and regional enteritis. Scand J Gastroenterol 1969;38:353-60.

15 Meijer CJLM, Bosman FT, Lindeman J. Evidence for predominant involvement of the B-cell system in the inflammatory process in Crohn's disease. Scand J Gastroenterol 1979;14:21-32.

16 Rosekrans PCM, Meijer CJLM, Lindeman J. Immunoglobulin containing cells in colonic and rectal mucosa in globulin containing cells in colonic and rectal mucosa in Crohn's disease. In: Pena AS, Weterman IT, Booth CC, Strober W, eds. Recent advances in Crohn's
Development in gastroenterology. Vol 1; 1981:94-9.

17 Seldenrijk CA, Drexhage HA, Meuwissen SGM, Pals ST, Meijer CJLM. Dendritic cells and scavenger macrophages in chronic inflammatory bowel disease. Gut 1989;30:484-91.

18 Bosman FT, Lindeman J, Kuipers G, van der Wal AM, Kreuning J. The influence of fixation on immunoreactivity of plasma cells in routinely processed intestinal biopsy specimens. In: Van Noorden S, Polak JM, eds. Immunocytochemistry: practical applications in pathology and biology. Bristol: Wright PSG, 1983:11-42.

19 Seldenrijk CA, Hendriks G, Smeulders AWM, et al. Reproducibility of counting immunoglobulin containing
cells in colonic mucosal biopsies. Anal Quant Cytol Histol 1988;2:94-100.

20 Dixon WJ, ed. BMDP Biomedical Computer Programs. Berkeley: University of California Press, 1983.

21 Baklien K, Brandtzaeg P. Comparative mapping of the distribution of immunoglobulin-containing cells in distribution of immunoglobulin-containing cells in Exp Immunol 1975;22:197-209.

22 Jewell DP, Patel C. Immunology of inflammatory bowel disease. Scand J Gastroenterol 1985;20:119-26. 
23 Keren DF, Appelman HD, Dobbins WO, et al. Correlation of histopathological evidence of disease activity with the presence of immunoglobulin-containing cells in the colon of patients with inflammatory bowel disease. Hum Pathol 1984;15:757-63.

24 van Spreeuwel JP, van der Wal AM, Weterman J, Kreuning J, Meyer CJIM Morphological and immunohistochemical findings in upper gastrointestinal biopsi patients with Crohn's disease of the ileum and colon Clin Pathol 1982;35:934-40.

25 Baklien K, Brandtzaeg P. Immunohistochemical characterisation of local immunoglobulin formation in Crohn's disease of the ileum Scand $J$ Gastroenterol 1976;11: 447-57.

26 Skinner JM, Whitehead $R$. The plasmacells in inflammatory disease of the colon: a quantitative study. J Clin Pathol 1974;27:643-6.

27 Van Spreeuwel JP, Lindeman J, Meijer CJLM. A Quantitative study of immunoglobulin containing cells in the differential diagnosis of acute colitis. J Clin Pathol 1985;38:774-7.

28 Söltoft J, Binder V, Gudmand-Höyer E. Intestinal immunoglobulins in ulcerative colitis. Scand $J$ Gastroenterol 1973;8:293-9. 